\title{
An Examination of Historical Literacy Perceptions of Social Studies Preservice Teachers in Terms of Various Variables
}

\author{
Osman Akhan ${ }^{1} \&$ Samet Çiçek ${ }^{2}$ \\ ${ }^{1}$ Akdeniz Universty, Faculty of Education, Antalya, Turkey \\ ${ }^{2}$ Akdeniz Universty, Institute of Educational Sciences, Antalya, Turkey \\ Correspondence: Osman Akhan, Akdeniz University, Faculty of Education, Dumlupınar Boulevard, 07058 \\ Campus Antalya, Turkey. Tel: 90-242-227-4401/4629. E-mail: osmanakhan@ akdeniz.edu.tr
}

Received: February 21, 2021

Accepted: April 10, $2021 \quad$ Online Published: April 13, 2021

doi:10.5539/hes.v11n2p166

URL: https://doi.org/10.5539/hes.v11n2p166

\begin{abstract}
The aim of this study is to determine the historical literacy perception levels of social studies preservice teachers and to examine them in terms of various variables. In this framework, the survey model, one of the quantitative research methods, was used in the research. The sample of this study consisted of 134 social studies preservice teachers studying at the faculty of education of a state university in the 2019-2020 academic year. The data in the study were collected with the "Historical Literacy Perception Scale" developed by Uluçay (2019), after obtaining the necessary permissions. The data obtained from the scale were analyzed using the statistical package program.

Considering the results obtained from the study, it was concluded that the social studies preservice teachers in the sample had high levels of historical literacy perception. In addition, their perception levels increased according to the variables of mother's education level and frequency of watching historical movies. On the other hand, their perceptions did not change / differ according to the variables such as grade level, gender, father's education level, tendency to read history books, to follow historical publications and competence of the teachers. Considering the results of the research in general, it can be said that the preservice teachers benefited sufficiently from their university and pre-university education in terms of historical literacy skills.
\end{abstract}

Keywords: social studies, preservice teacher, historical literacy, perception

\section{Introduction}

History (Allen \& Stevens, 1998), which has an existence beyond our knowledge and is defined as both the past of humanity and the record of the past (Allen \& Stevens, 1998), is basically a discipline that describes the activities of people who lived in the past in a cause and effect relationship by specifying the place and time (Köstüklü, 2006). In this context, one of the main disciplines that primary education social studies course (Garcia \& Michaelis, 2001) utilizes for its content and working methods taken from social science disciplines is history (Sunal \& Haas, 2005; Kabapınar, 2014). Students' ability to understand the present in the context of the past and to orient themselves in time by foreseeing the future depends on their ability to use the past and their understanding of history (Lee, 2005). Historical consciousness, which expresses an intergenerational mental orientation regarding time, is based on the ability to think back and forth in time. In other words, it means constructing expectations for the future by making sense of the past (Ahonen, 2005). Instead of creating a narrow perception of history in the teaching of subjects of history in the social studies course, it is important to strengthen the students' loyalty to their country by developing their historical thinking skills (Ersoy \& Öztürk, 2015). Seixas (2017). Defining students' historical thinking skills as their ability to negotiate productive solutions, Seixas (2017) suggested the following concepts concerning historical thinking:

- Historical Importance,

- Evidence, Continuity and Change,

- Cause and Effect,

- Taking a Historical Perspective,

- Moral / Ethical dimension.

These concepts were proposed as a broader idea of developing a historical consciousness defined as the current 
awareness of the past and the connection between them. The concept of "Historical Thinking" proposed by history educators is a term emphasizing that history education is not based on rote memorization. The examination, analysis and interpretation of events from different perspectives show that topics of history deserve more significance than a "rote" approach (Parkes \& Donnelly, 2014). Historical literacy, which is also associated with historical thinking skills and has an inclusive nature, is a skill that contributes to students' being knowledgeable / effective citizens in their future lives (Bennett, 2014). Historical literacy is concerned with specific skills, attitudes and conceptual understandings that mediate and develop historical consciousness (Taylor \& Young, 2003).

Historical literacy involves understanding what history is, realizing importance of historical events and recognizing rules of history, and organizing concepts such as the past, event, cause and effect that is emphasized in the method of the discipline of history (Ata \& Keçe, 2014). Historical literacy proposes a more integrated perspective regarding the elements of history education (narrative structures that shape historical understanding, development of historical reasoning competencies, contextualization ability, textbooks, etc.), which are main areas of interest in contemporary sciences, and it develops historical awareness (Baildon \& Afandi, 2018). Students should develop historical literacy skills, which are a set of skills that provide them with tools to understand a text from a historical period. That's because in a historical period, the true historical understanding of a person, place or event requires historical literacy (Walker, 2006). Since history is a discipline open to interpretation (Akıncı, 2020), including historical thinking skills in the process and raising students with high historical literacy skills are important considerations in the teaching of historical topics (Keçe, 2015). When the relevant literature is examined, one encounters studies indicating that students' historical literacy levels are lower than the desired level (Keçe, 2009; Keçe, 2013; Ata \& Keçe, 2014; Ouakrim-Soivio \& Kuusela, 2012, cited in Khawaja, 2018; Veijola \& Rantala, 2018. ). Considering that subjects of history at primary education are included in the social studies course via an interdisciplinary approach, it is important to determine, in the preservice period, the historical literacy perception levels of social studies teachers, who are conductors and practitioners of this course. In this framework, the aim of the study is to determine the historical literacy perception levels of social studies preservice teachers and to examine them in terms of various variables.

\section{Method}

\subsection{Research Model}

The survey model, one of the quantitative research methods, was used in this study, which aimed to determine the historical literacy perception levels of social studies preservice teachers. "Survey models are research approaches that aim to describe a past or present situation as it exists" (Karasar, 2005: 77).

\subsection{Sample}

The sample of this study consisted of 134 social studies preservice teachers at the education faculty of a state university in the 2019-2020 academic year who were selected using the convenience sampling method studying in the 2019-2020 academic year. The convenience sampling method was preferred in the study because of its "accessibility, ease of access, and addition of speed and practicality to the study" (Yıldırım \& Şimşek, 2016). Some descriptive information about the sample is as follows: 
Table 1. Descriptive information about the sample

\begin{tabular}{llll}
\hline & & N & \% \\
\hline Gender & Female & 95 & 70,8 \\
Grade & Male & 39 & 29,1 \\
& 1 & 34 & 25,3 \\
& 2 & 30 & 22,3 \\
Mother's Education Level & 3 & 29 & 21,6 \\
& 4 & 41 & 30,6 \\
Father's Education Level & Middle School and below & 95 & 70,8 \\
& High school and below & 39 & 29,1 \\
Liking/Disliking to Read History Books & Middle School and below & 80 & 59,7 \\
& High school and below & 54 & 40,2 \\
Following Historical Publications Regularly y & Likes & 105 & 78,3 \\
& Dislikes & 29 & 21,6 \\
& Nes & 24 & 17,9 \\
Watching Historical Movies & No & 110 & 82 \\
& Never & 26 & 19,4 \\
Teacher's Competence & Once a Week & 28 & 20,8 \\
& Once a Month & 80 & 59,7 \\
Order of Interest in History & Yes & 106 & 79,1 \\
& No & 28 & 20,8 \\
& 1 & 46 & 34,3 \\
& 2 & 35 & 26,1 \\
& 3 & 39 & 29,1 \\
Out-of-Class History Learning Methods & Drama & 14 & 10,4 \\
& Film-Series & 18 & 13,4 \\
& Museum-Trip & 23 & 17,1 \\
& Documentary & 52 & 38,8 \\
& & 41 & 30,5 \\
\hline
\end{tabular}

\subsection{Data Collection}

The data of this study were collected using the "Historical Literacy Perception Scale" developed by Uluçay (2019) after obtaining the necessary permissions. This scale is a 5-point Likert type scale with 12 items developed for preservice teachers. The items in the scale prepared in accordance with the Likert-type scale model were graded as "(5) Strongly Agree", "(4) Agree", "(3) Rarely", "(2) Disagree", and "(1) Strongly Disagree". The validity-reliability study revealed that the scale had a three-dimensional structure, and the distribution of the dimensions to the scale items was as follows.

Items in the first factor: Items 1, 2 and 3

Items in the second factor: Items 4, 5, 6, 10, 11 and 12

Items in the third factor: Items 7, 8 and 9

When the items under each factor were examined in terms of content, it was seen that the first factor could be named "Perception", the second factor "Objectivity" and the third factor "Consistency". For example, while the item "I keep historical events in my mind easily" was included in the first factor, the item "I want a narrative teaching to be used in teaching a historical event" was in the second factor and the item "Historical information in the virtual environment does not sound reliable to me" was included in the third factor. In the reliability analysis of the scale, the Cronbach Alpha value was found to be $(\alpha=, 660)$ and the scale was accepted to be quite reliable.

\subsection{Data Analysis}

The statistical package program (SPSS) was used to analyze the data obtained from the scale in the study. The kurtosis and skewness values of the scores were examined to determine whether the scores obtained from the sub-dimensions of the scale had a normal distribution in the selection of the analyses to be made within the scope of the study. In this context, a score distribution with kurtosis and skewness values between -1 and +1 was accepted as a normal distribution; otherwise, it was considered not to have a normal distribution. In line with the 
aims of the study, it was examined whether the scores obtained from the sub-dimensions of the scale exhibited a statistically significant difference according to the categories of the determined independent variables. In this context, when the distribution of the scores belonging to the sub-dimension was normal in each category of the relevant independent variable, t-test was used for unrelated samples if the number of categories was two, and ANOVA analysis was used if the number of categories was more than two. If the score distributions of the measurements were not normal in each category of the relevant independent variable, unrelated samples Mann Whitney $U$ test was used if the number of categories was two, and the Kruskall Wallis test was used if the number of categories was more than two.

\section{Findings}

\subsection{Total Scores Received By the Social Studies Preservice Teachers in the Sample from the "Historical Literacy Perception Scale"}

The descriptive statistics of the scores received by the students from the whole of the historical literacy scale and its sub-dimensions within the scope of the study are shown in Table 2.

Table 2. Descriptive statistics of the scores received by the students from the whole and sub-dimensions of the historical literacy scale

\begin{tabular}{lllll}
\hline Scale & $\overline{\boldsymbol{X}}$ (item average) & S. Deviation & Min. & Max. \\
\hline Historical literacy total & $44,40(3,70)$ & 4,55 & 26 & 60 \\
Perception & $9,99(3,33)$ & 2,37 & 4 & 15 \\
Objectivity & $26,27(4,38)$ & 3,57 & 6 & 30 \\
Consistency & $8,18(2,73)$ & 1,99 & 3 & 15 \\
\hline
\end{tabular}

An examination of the descriptive statistics of the historical literacy total scores in Table 2 reveals that the average score is 44.40 and item average is 3.70 . Considering that the medium level of an item corresponds to 2.5 in a Likert type measuring instrument, it can be said that the historical literacy scores of the participants are high. According to the results obtained, while the minimum score that the students received from historical literacy is 26 , the maximum score is 60 . When the descriptive statistics of the scores of the perception sub-dimension are considered, it is seen that the mean score is 9.99 and item average is 3.33. Considering that the medium level of an item corresponds to 2.5 in a Likert type measuring instrument, it can be said that the participants' scores from the Perception sub-dimension are high. According to the results obtained, while the minimum score received from the Perception sub-dimension is 4, the maximum score is 15 . An examination of the descriptive statistics of the scores belonging to the Objectivity sub-dimension reveals that the mean score is 26.27 and item average is 4.38. Considering that the medium level of an item corresponds to 2.5 in a Likert type measurement instrument, it can be said that the participants' scores from the Objectivity sub-dimension are high. According to the research results, while the minimum score received from the objectivity sub-dimension is 6 , the maximum score is 30 . An examination of the descriptive statistics of the scores belonging to the Consistency sub-dimension reveals that the mean score is 8.18 and item average is 2.73 . Considering that the medium level of an item corresponds to 2.5 in a Likert type measuring instrument, it can be said that the scores of the participants from the Consistency sub-dimension are at a medium level. According to the results obtained, while the minimum score received from the Consistency sub-dimension is 3 , the maximum score is 15 . 
3.2 Distribution of the Answers of the Social Studies Preservice Teachers in the Sample to the Items of "Historical Literacy Perception Scale"

Table 3. Distribution of the 1tems of the students' historical literacy scale by their options

\begin{tabular}{lllllllllll}
\hline Item & \multicolumn{2}{l}{ Strongly Disagree } & \multicolumn{2}{l}{ Disagree } & \multicolumn{2}{l}{ Rarely } & \multicolumn{2}{l}{ Agree } & \multicolumn{2}{l}{ Strongly Agree } \\
\cline { 2 - 10 } & $\mathbf{f}$ & \% & f & \% & f & \% & f & \% & f & \% \\
\hline I1 & 6 & 4,47 & 5 & 3,73 & 66 & 49,25 & 38 & 28,36 & 19 & 14,18 \\
$\mathbf{I 2}$ & 0 & 0 & 14 & 10,45 & 39 & 29,10 & 65 & 48,51 & 16 & 11,94 \\
$\mathbf{I 3}$ & 17 & 12,69 & 21 & 15,67 & 63 & 47,01 & 21 & 15,67 & 12 & 8,96 \\
$\mathbf{I 4}$ & 6 & 4,48 & 2 & 1,49 & 15 & 11,19 & 39 & 29,10 & 72 & 53,73 \\
$\mathbf{I 5}$ & 2 & 1,49 & 0 & 0 & 7 & 5,22 & 14 & 10,45 & 111 & 82,84 \\
$\mathbf{I 6}$ & 2 & 1,49 & 4 & 2,99 & 5 & 3,73 & 30 & 22,39 & 93 & 69,40 \\
$\mathbf{I 7}$ & 7 & 5,22 & 21 & 15,67 & 70 & 52,24 & 25 & 18,66 & 11 & 8,21 \\
$\mathbf{I 8}$ & 12 & 8,96 & 36 & 26,87 & 61 & 45,52 & 19 & 14,18 & 6 & 4,48 \\
$\mathbf{I 9}$ & 29 & 21,64 & 47 & 35,07 & 45 & 33,58 & 11 & 8,21 & 2 & 1,49 \\
$\mathbf{I 1 0}$ & 2 & 1,49 & 5 & 3,73 & 15 & 11,19 & 43 & 32,09 & 69 & 51,49 \\
$\mathbf{I 1 1}$ & 2 & 1,49 & 2 & 1,49 & 17 & 12,69 & 63 & 47,01 & 50 & 37,31 \\
$\mathbf{I 1 2}$ & 5 & 3,73 & 4 & 2,99 & 16 & 11,94 & 27 & 20,15 & 82 & 61,19 \\
\hline
\end{tabular}

It is seen in Table 3 that for Item 1, 6 of the students $(4.47 \%)$ chose the option strongly disagree, 5 (3.73\%) disagree, $66(49.25 \%)$ rarely, $38(28.36 \%))$ agree and $19(14.18 \%)$ strongly agree. When the frequencies and percentages are examined in terms of students' keeping historical events in mind easily, it can be said that the vast majority of the students rarely exhibited this behavior, and among the remaining students, those who exhibited this behavior outnumbered those who did not.

As can be seen from Table 3, for Item 2, 14 (10.45 \%) of the students chose the option disagree, 39 (29.10\%) rarely, $65(48.51 \%)$ agree and $16(14,18 \%)$ strongly agree. When the frequencies and percentages are examined in terms of the students' making sense of the historical language used in the lessons, it can be said that the majority of the students exhibited such behavior, and among the remaining students, those who rarely exhibited that behavior outnumbered those who did not.

It is seen in Table 3 that for Item 3, 17 of the students (12.69 \%) chose the option strongly disagree, 21 (15.67\%) disagree, $63(47.01 \%)$ rarely, $21(15.67 \%)$ agree and $12(8.96 \%)$ strongly agree. When the frequencies and percentages are examined in terms of not forgetting the dates of historical events, it can be said that the vast majority of the students rarely exhibited such behavior, and among the remaining students, those who did not exhibit that behavior slightly outnumbered those who did.

As can be seen from Table 3, for Item 4, 6 (4.48 \%) of the students chose the option strongly disagree, 2 (1.49\%) disagree, $15(11.19 \%)$ rarely, $39(29,10 \%)$ agree and $72(53.73 \%)$ strongly agree. When the frequencies and percentages are examined in terms of their preference for a narrative teaching while teaching a historical event, it can be said that the majority of the students preferred narrative teaching, and among the remaining students, those who rarely preferred it outnumbered those who did not.

It is seen in Table 3 that for Item 5, 2 students (4.47 \%) chose the option strongly disagree, 7 (5.22 \%) rarely, 14 $(10.45 \%)$ agree, and $111(82.84 \%)$ ) strongly agree. When the frequencies and percentages are examined in terms of believing that different sources related to a historical event should be scientific and objective, it can be said that most of the students believed that the sources should be scientific and objective, and among the remaining students, those who rarely believed outnumbered those who did not.

As can be seen from Table 3, for Item 6, 2 (1.49\%) students chose the option strongly disagree, 4 (2.99 \%) disagree, $5(3.73 \%)$ rarely, $30(22,39 \%)$ agree and $93(69.40 \%)$ strongly agree. When the frequencies and percentages are examined in terms of understanding the text more easily when reading historical texts whose statements are objective and clear, it can be said that the majority of the students exhibited such behavior, and among the rest of the students, those who did not exhibit such behavior slightly outnumbered those who rarely exhibited it.

It is seen in Table 3 that for Item 7, 7 (5.22 \%) students chose the option strongly disagree, $21(15.67 \%)$ disagree, $70(52.24 \%)$ rarely, $25(18.66 \%)$ agree and $11(8.21 \%)$ strongly agree. When the frequencies and percentages are examined in terms of their not trusting the historical information in the virtual environment, it can be said that the vast majority of the students rarely did not trust, and among the remaining students, those who did not 
trust outnumbered those who did.

As can be seen from Table 3, for Item 8, $12(8.96 \%)$ of the students chose the option strongly disagree, 36 $(26.87 \%)$ disagree, $61(45.52 \%)$ rarely, $19(14.18 \%)$ agree, and $6(4.48 \%)$ strongly agree. When the frequencies and percentages are examined in terms of their interpretation of the historical language used in historical works, it can be said that most of the students rarely exhibited such behavior and among the rest of the students, those who did not exhibit this behavior outnumbered those who did.

It is seen in Table 3 that for Item 9, 29 of the students (21.64 \%) chose the option strongly disagree, $47(35.07 \%)$ disagree, $45(33.58 \%)$ rarely, $11(8.21 \%)$ agree, and $2(1.49 \%)$ strongly agree. When the frequencies and percentages are examined in terms of their keeping in mind how historical events occurred, it can be said that the vast majority of the students rarely exhibited such behavior, and among the rest of the students, those who did not exhibit that behavior outnumbered those who did.

As can be seen from Table 3, for Item 10, $2(1.49 \%)$ students chose the option strongly disagree, 5 (3.73\%) disagree, $15(11.19 \%)$ rarely, $43(32.09 \%)$ agree and $69(51.49 \%)$ strongly agree. When the frequencies and percentages are examined in terms of liking to watch movies about historical events, it can be said that the majority of the students liked them and among the remaining students, those who rarely liked them outnumbered those who did not.

It is seen in Table 3 that for Item 11, $2(1.49 \%)$ students chose the option strongly disagree, $2(1.49 \%)$ disagree, $17(12.69 \%)$ rarely, $63(47.01 \%)$ agree and $50(37.31 \%)$ strongly agree. When the frequencies and percentages are examined in terms of remembering the people who played an important role in history, it can be said that the majority of the students rarely exhibited such behavior and among the remaining students, those who rarely exhibited that behavior outnumbered those who did not.

As can be seen from Table 3, for Item 12, $5(3.73 \%)$ students chose the option strongly disagree, $4(2.99 \%)$ disagree, $16(11.94 \%)$ rarely, $27(20.15 \%)$, agree and $82(61.19 \%)$ strongly agree. When the frequencies and percentages are examined in terms of preferring to narrate the events in today's Turkish when teaching about historical events, it can be said that most of the students preferred this behavior and among the remaining students, those who rarely preferred this behavior outnumbered those who did not.

3.3 Examination of the Scores Received by the Social Studies Preservice teachers in the Sample from the "Historical Literacy Perception Scale" and its Sub-Dimensions According to the Grade Level Variable

The results of the Kruskall Wallis Test and ANOVA applied to examine whether the scores obtained within the scope of the study from the historical literacy scale and its sub-dimensions differred according to grade levels of the students are shown in Table 4.

Table 4. Kruskall Wallis test and ANOVA Results regarding comparison of the students' scores obtained from the historical literacy scale and its sub-dimensions by grade level

\begin{tabular}{llllllll}
\hline ANOVA & $\begin{array}{l}\text { Source of } \\
\text { variance }\end{array}$ & $\begin{array}{l}\text { Sum of } \\
\text { squares }\end{array}$ & $\begin{array}{l}\text { Mean of } \\
\text { squares }\end{array}$ & sd & F & p & Difference \\
\hline Perception & Inter-group & 5,76 & 1,92 & 3 & 0,34 & 0,80 & \\
& Intra-group & 742,21 & 5,71 & 131 & & & \\
& Total & 747,97 & & 134 & & & \\
Consistency & Inter-group & 1,29 & 0,43 & 3 & 0,11 & 0,96 & \\
& Intra-group & 528,41 & 4,10 & 131 & & & \\
Kruskall-Wallis & Total & 529,70 & & 134 & & & \multirow{2}{*}{ Difference } \\
Total & Group & N & Mean Rank & sd & Chi-square & p \\
& 1st Grade & 34 & 62,40 & 3 & 1,64 & 0,65 & \\
& 2nd Grade & 30 & 74,67 & & & & \\
& 3rd Grade & 30 & 66,55 & & & & \\
Objectivity & 4th Grade & 40 & 67,18 & & & & \\
& 1st Grade & 34 & 66,71 & 3 & 4,03 & 0,26 & \\
& 2nd Grade & 30 & 79,40 & & & & \\
& 3rd Grade & 30 & 64,28 & & & & \\
& 4th Grade & 40 & 61,66 & & & & \\
\hline
\end{tabular}

In Table 4, when the Kruskall Wallis Test and ANOVA results applied according to the grade level variable for the scores obtained from the whole of the historical literacy scale and its sub-dimensions were examined, it was 
found that the scores did not show a statistically significant difference according to the students' grade levels ( $\mathrm{p}>$ 0.05). In other words, the historical literacy total, perception, consistency and objectivity scores of the students at all grade levels were similar.

\subsection{Examination of the Social Studies Preservice teachers' Scores Received from the "Historical Literacy} Perception Scale" and Its Sub-Dimensions According to the Gender Variable

The results of the T Test and Mann Whitney U Test applied within the scope of the study to examine whether the scores obtained by the students from the Historical Literacy Scale and its sub-dimensions differed according to the gender of the students are shown in Table 5.

Table 5. T test and Mann Whitney U test results of the comparison of the students' scores obtained from the historical literacy scale and its sub-dimensions by gender

\begin{tabular}{lllllll}
\hline T Test & Group & $\mathbf{N}$ & Mean & sd & t & p \\
\hline Perception & Male & 39 & 10,41 & 132 & 1,33 & 0,19 \\
& Female & 95 & 9,81 & & & \\
Consistency & Male & 39 & 8,33 & 132 & 0,57 & 0,57 \\
& Female & 95 & 9,12 & & & \\
Mann Whithney U U & Group & $\mathbf{N}$ & Mean Rank & Sum of Rank & $\mathbf{U}$ & $\mathbf{p}$ \\
Total & Male & 39 & 76,90 & 2999,00 & 1486,00 & 0,07 \\
& Female & 95 & 63,64 & 6046,00 & & \\
Objectivity & Male & 39 & 72,28 & 2819,00 & 1666,00 & 0,36 \\
& Female & 95 & 65,54 & 6226,00 & & \\
\hline
\end{tabular}

In Table 5, When the results of T Test and Mann Whitney $\mathrm{U}$ test applied according to the gender variable for the scores obtained from the whole and sub-dimensions of the Historical Literacy Scale were examined, it was determined that the scores did not show a statistically significant difference according to the gender of the students $(p>0.05)$. In other words, the historical literacy total, perception, consistency and objectivity scores of the male and female students participating in the study were similar.

3.5 Examination of the Scores Received by the Social Studies Preservice teachers in the Sample from the "Historical Literacy Perception Scale" and its Sub-Dimensions According to Mother's Education Level Variable

The results of the T Test and the Mann Whitney U test applied within the scope of the study to examine whether the scores obtained from the historical literacy scale and its sub-dimensions differed according to the education levels of the students' mothers are given in Table 6.

Table 6. Mann Whitney U test results on the comparison of the students' scores obtained from the historical literacy scale and its sub-dimensions according to their mothers' education levels

\begin{tabular}{lllllll}
\hline $\begin{array}{l}\text { Mann } \\
\text { Whithney U }\end{array}$ & Group & N & $\begin{array}{l}\text { Mean } \\
\text { Rank }\end{array}$ & $\begin{array}{l}\text { Sum of } \\
\text { Rank }\end{array}$ & U & p \\
\hline Total & Middle School and below & 95 & 61,87 & 5878,00 & $1318,00(-2,63)$ & $0,01^{*}$ \\
& High School and below & 39 & 81,21 & 3167,00 & & \\
Perception & Middle School and below & 95 & 63,63 & 6044,50 & 1484,50 & 0,07 \\
& High School and below & 39 & 76,94 & 3000,50 & & \\
\multirow{2}{*}{ Objectivity } & Middle School and below & 95 & 63,56 & 6038,50 & 1478,50 & 0,06 \\
& High School and below & 39 & 77,09 & 3006,50 & & \\
Consistency & Middle School and below & 95 & 65,72 & 6243,00 & 1683,00 & 0,400 \\
& High School and below & 39 & 71,85 & 2802,00 & & \\
\hline
\end{tabular}

In Table 6, when the results of the Mann Whitney U test, which was applied to the whole of the historical literacy scale, and the scores obtained according to the variable of mother's education level were examined, it was found that the scores differed statistically significantly according to the students' mothers' education levels $(z=-2.63, p$ $=0 ., 01 ; \mathrm{p}<0.05)$. When the difference was examined, it was determined that the historical literacy scores of the students whose mothers' education levels were high school and above were higher than those whose mothers' education levels were middle school and below. However, when the results of the Mann-Whitney U test applied according to mother's education level for the scores obtained from the sub-dimensions of the scale were examined, it was found that the scores did not show a statistically significant difference according to the students' mothers' education levels ( $\mathrm{p}>0.05)$. In other words, the perception, consistency and objectivity scores of the 
students in the study showed similarities, regardless of whether their mothers' education levels were middle school and below or high school and above.

3.6 Examination of the Scores Recevied by the Social Studies Preservice Teachers in the Sample from the "Historical Literacy Perception Scale" and its Sub-Dimensions According to Father's Education Level

The results of the T Test and the Mann Whitney U test applied within the scope of the research to examine whether the scores received by the students from the 'historical literacy scale and its sub-dimensions differed according to the education levels of the students' fathers are given in Table 7.

Table 7. T test and Mann Whitney $\mathrm{U}$ test results for the comparison of students' scores obtained from the historical literacy scale and its sub-dimensions according to father's education level

\begin{tabular}{lllllll}
\hline T Test & Group & N & Mean & sd & t & p \\
\hline Perception & Middle School and below & 80 & 9,80 & 132 & $-1,10$ & 0,27 \\
& High School and below & 54 & 10,26 & & & \\
Consistency & Middle School and below & 80 & 8,35 & 132 & 1,21 & 0,23 \\
& High School and below & 54 & 7,93 & & & \\
Mann Whithney U U & Group & $\mathbf{N}$ & Mean Rank & Sum of Rank & U & p \\
Total & Middle School and below & 80 & 66,57 & 5325,50 & 2085,50 & 0,73 \\
& High School and below & 54 & 68,88 & 3719,50 & & \\
Objectivity & Middle School and below & 80 & 66,26 & 5301,00 & 2061,00 & 0,65 \\
& High School and below & 54 & 69,33 & 3744,00 & & \\
\hline
\end{tabular}

In Table 7, When the results of the $\mathrm{T}$ test and Mann Whitney $\mathrm{U}$ test applied according to the father's education level variable for the scores obtained from the whole of the historical literacy scale and its sub-dimensions were examined, it was found that the scores did not show statistically significant difference according to the education levels of the students' fathers ( $p>0.05$ ). In other words, the historical literacy total, perception, consistency and objectivity scores of the students in the sample were similar, regardless of whether their fathers' education levels were middle school and below, or high school and above.

3.7 Examination of the Scores Received by the Social Studies Preservice Teachers in the Sample from the "Historical Literacy Perception Scale" and its Sub-Dimensions According to the Variable of Liking to Read History Books

The results of the T Test and the Mann Whitney $U$ test applied within the scope of the research to examine whether the scores obtained by the students from the 'historical literacy scale" and its sub-dimensions differed according to the students' liking to read history books are shown in Table 8.

Table 8. T test and Mann Whitney U test results for the comparison of students' scores obtained from the historical literacy scale and its sub-dimensions according to liking to read history books

\begin{tabular}{lllllll}
\hline T Test & Group & $\mathbf{N}$ & Mean & sd & t & p \\
\hline Perception & Likes & 105 & 10,00 & 132 & 0,21 & 0,83 \\
& Dislikes & 29 & 9,89 & & & \\
Consistency & Likes & 105 & 8,16 & 132 & $-0,12$ & 0,90 \\
& Dislikes & 29 & 8,21 & & & \\
Mann Whithney U & Group & $\mathbf{N}$ & Mean Rank & Sum of Rank & U & p \\
Total & Likes & 105 & 66,38 & 6970,00 & 1405,00 & 0,72 \\
& Dislikes & 29 & 69,32 & 1941,00 & & \\
Objectivity & Likes & 105 & 66,62 & 6995,00 & \multirow{2}{*}{1430,00} & 0,82 \\
& Dislikes & 29 & 68,43 & 1916,00 & & \\
\hline
\end{tabular}

In Table 8, when the results of the $\mathrm{T}$ test and the Mann Whitney $\mathrm{U}$ test applied according to the variable of liking to read history books for the scores obtained from the whole of the historical literacy scale and its sub-dimensions were examined, it was found that the scores did not differ statistically according to the students' liking to read history books ( $p>0.05$ ). In other words, the historical literacy total, perception, consistency and objectivity scores of the students who liked and disliked reading history books were similar. 
3.8 Examination of the Scores Received by the Social Studies Preservice teachers from the "Historical Literacy Perception Scale" and Its Sub-Dimensions According to the Variable of Following Historical Publications

The results of T Test and Mann Whitney U test applied within the scope of the research to examine whether the scores obtained by the students from the historical literacy scale and its sub-dimensions differed according to the students' following historical publications are shown in Table 9.

Table 9. T test and Mann Whitney U test results for the comparison of the students' scores obtained from the historical literacy scale and sub-dimensions according to their following historical publications

\begin{tabular}{lllllll}
\hline T Test & Group & N & Mean & sd & t & p \\
\hline Perception & Follows/Yes & 24 & 10,13 & 132 & 0,34 & 0,74 \\
& Does not Follow/No & 110 & 9,95 & & & \\
Consistency & Follows & 24 & 8,35 & 132 & 0,46 & 0,65 \\
& Does not Follow & 110 & 8,14 & & & \\
Mann Whithney U U & Group & $\mathbf{N}$ & Mean Rank & Sum of Rank & U & $\mathbf{p}$ \\
Total & Follows & 24 & 76,11 & 1750,50 & 1055,50 & 0,21 \\
& Does not Follow & 110 & 65,10 & 7160,50 & & \\
Objectivity & Follows & 24 & 71,43 & 1643,00 & 1163,00 & 0,54 \\
& Does not Follow & 110 & 66,07 & 7268,00 & & \\
\hline
\end{tabular}

In Table 9, when the T test and Mann Whitney $U$ test applied for the scores obtained from the whole of the historical literacy scale and its sub-dimensions according to the variable of following historical publications were examined, it was found that the scores did not show a statistically significant difference according to the students' following historical publications ( $p>0.05$ ). In other words, the historical literacy total, perception, consistency and objectivity scores of the students who followed and did not follow historical publications were similar.

3.9 Examination of the Scores Received by the Social Studies Preservice Teachers in the Sample from the "Historical Literacy Perception Scale" and its Sub-Dimensions According to the Variable of Frequency of Watching Historical Movies

The results of the Kruskall Wallis Test and ANOVA applied within the scope of the study to examine whether the scores the students received from the historical literacy scale and its sub-dimensions differed according to the frequency of their watching historical movies are shown in Table 10.

Table 10. Kruskall Wallis test and ANOVA results regarding the comparison of the students' scores received from the historical literacy scale and its sub-dimensions according to the frequency of watching historical movies

\begin{tabular}{|c|c|c|c|c|c|c|c|}
\hline ANOVA & $\begin{array}{l}\text { Source of } \\
\text { variance }\end{array}$ & $\begin{array}{l}\text { Sum of } \\
\text { squares }\end{array}$ & $\begin{array}{l}\text { Mean of } \\
\text { squares }\end{array}$ & sd & $\mathbf{F}$ & $\mathbf{p}$ & Difference \\
\hline \multirow[t]{3}{*}{ Perception } & Inter-group & 25,52 & 12,76 & 3 & 2,31 & 0,10 & \\
\hline & Intra-group & 722,45 & 5,52 & 131 & & & \\
\hline & Total & 747,97 & & 134 & & & \\
\hline \multirow[t]{3}{*}{ Consistency } & Inter-group & 4,10 & 2,04 & 3 & 0,51 & 0,60 & \\
\hline & Intra-group & 525,63 & 4,01 & 131 & & & \\
\hline & Total & 529,70 & & 134 & & & \\
\hline Kruskall-Wallis & Group & $\mathbf{N}$ & Mean Rank & sd & Chi-square & p & Difference \\
\hline \multirow[t]{3}{*}{ Total } & Never & 26 & 43,83 & 2 & 12,14 & $0,00^{*}$ & \\
\hline & Once a Month & 80 & 73,68 & & & & \\
\hline & Once a Week & 28 & 71,84 & & & & \\
\hline \multirow[t]{3}{*}{ Objectivity } & Never & 26 & 45,31 & 2 & 10,89 & $0,00^{*}$ & \\
\hline & Once a Month & 80 & 73,58 & & & & \\
\hline & Once a Week & 28 & 70,75 & & & & \\
\hline
\end{tabular}

In Table 10, when the results of ANOVA applied for the scores obtained from the whole of the historical literacy scale and the objectivity sub-dimension according to the frequency of watching historical movies were examined, it was determined that the scores showed a statistically significant difference according to the frequency of students' watching historical movies $\left(\chi\right.$ Total $^{\wedge} 2=12.14, \mathrm{p}=0.00 ; \chi \_$objectivity ${ }^{\wedge} 2=10.89, \mathrm{p}=0.00 ; \mathrm{p}<0.05$ ). As a result of the paired comparisons made to determine the source of the difference, it was concluded that the historical literacy total scores and objectivity scores of the students who watched a historical film once a month 
or a week were similar to each other and they were higher than the scores of those who never watched a historical film. However, when the ANOVA results applied for the scores obtained from the perception and consistency sub-dimensions of the scale according to the variable of frequency of watching historical movies were examined, it was found that the scores did not show a statistically significant difference according to the frequency of students' watching historical movies ( $p>0.05$ ). In other words, the perception and consistency scores of the students in the study were similar regardless of their frequency of watching historical movies.

\subsection{Examination of the Social Studies Preservice Teachers' Scores Received from the "Historical Literacy Perception Scale" and Its Sub-Dimensions According to the Variable of The Effect of Teacher's Competence on} Students' Perceptions

The results of T Test and Mann Whitney U test applied within the scope of the research to examine whether the scores obtained by the students from the historical literacy scale and its sub-dimensions differed according to the effect of teacher's competence on students' perceptions are given in Table 11.

Table 11. T test and Mann Whitney U test results for the comparison of the students' scores received from the historical literacy scale and sub-dimensions according to the variable of teacher's competence

\begin{tabular}{lllllll}
\hline T Test & Group & $\mathbf{N}$ & Mean & sd & $\mathbf{t}$ & $\mathbf{p}$ \\
\hline Perception & Yes & 107 & 9,98 & 132 & $-0,04$ & 0,97 \\
& No & 28 & 10,00 & & & \\
Consistency & Yes & 107 & 8,31 & 132 & 1,69 & 0,10 \\
& No & 28 & 7,58 & & & \\
Mann Whithney & Group & $\mathbf{N}$ & Mean Rank & Sum of Rank & U & $\mathbf{p}$ \\
Total & Yes & 107 & 68,73 & 7354,50 & 1205,50 & 0,29 \\
& No & 28 & 59,87 & 1556,50 & & \\
Objectivity & Yes & 107 & 68,50 & 7329,00 & 1231,00 & 0,36 \\
& No & 28 & 60,85 & 1582,00 & & \\
\hline
\end{tabular}

In Table 11, when the results of the $\mathrm{T}$ test and Mann Whitney $\mathrm{U}$ test applied for the scores obtained from the whole and sub-dimensions of the historical literacy scale according to the effect of teacher's competence on students' perceptions were examined, it was found that the scores did not show a statistically significant difference according to the effect of teacher's competence on students' perceptions ( $p>0.05)$. In other words, the historical literacy total, perception, consistency and objectivity scores of the students who were affected by the competence of their teachers and those who were not showed similarities.

\section{Conclusion, Discussion and Suggestions}

In this study, which was conducted to determine the historical literacy perception levels of social studies preservice teachers and to examine them in terms of various variables, it was concluded that when the "Historical Literacy Perception Scale" developed by Uluçay (2019) was applied to the pre-service teachers, the average scores $(44,40)$ they received from the scale were high. Accordingly, it can be said that the preservice teachers' historical literacy perception levels were high. This finding can be attributed to the fact that the preservice teachers were positively affected by the education they received before they started university and the history-related courses they had during their university education. When the scores obtained from the sub-dimensions of the "Historical Literacy Perception Scale" were evaluated, it was seen they had an average score of 9.99 in the perception sub-dimension, 26.27 in the objectivity sub-dimension, and 8.18 in the consistency sub-dimension. According to these results, it can be said that the scores of the perception and objectivity sub-dimensions were high, whereas the scores of the consistency sub-dimension were at a medium level. The average scores obtained from the sub-dimensions indicate that the social studies preservice teachers in the sample had high levels of historical literacy perceptions.

When the distribution of the social studies preservice teachers' responses to the items is evaluated, it can be said that in terms of keeping historical events in mind easily, the majority of the students rarely exhibited this behavior and among the remaining students, there were more students who exhibited this behavior than those who did not. In terms of understanding the historical language used in the lessons, the vast majority of the students exhibited this behavior and among the remaining students, those who rarely exhibited this behavior outnumbered those who did not. In terms of not forgetting the dates of historical events, the vast majority of the students rarely exhibited this behavior, and among the remaining students, there were slightly more students who did not exhibit this behavior than those who did. 
In terms of preferring a narrative teaching while telling a historical event, the vast majority of the students preferred a narrative teaching, and among the rest of the students, those who rarely preferred it outnumbered those who did not. In terms of believing that different sources about a historical event should be scientific and objective, it was observed that the vast majority of the students believed that the sources should be scientific and objective, and among the remaining students, those who rarely believed outnumbered those who did not. In terms of understanding the text more easily when the statements were objective and clear in historical texts, it can be said that the majority of the students exhibited this behavior, but among the remaining students, those who did not exhibit this behavior were slightly more than those who rarely did so. In terms of not trusting the historical information in the virtual environment, the vast majority of the students reported that they rarely 'did not trust it', but among the remaining students, there were more students who reported they 'did not trust it' $i$ than those who did. In addition, it can be said, based on the responses given by the preservice teachers to the items, that the majority of the students rarely exhibited this behavior in terms of their understanding the historical language used in historical works and that among the remaining students, those who did not exhibit this behavior outnumbered those who did.

In terms of keeping in mind how historical events occurred, the vast majority of the students rarely exhibited this behavior, and among the remaining students, there were more students who did not exhibit this behavior than those who did. It can be said that the majority of the students enjoyed watching movies about historical events, and among the rest of the students, those who rarely enjoyed them were more than those who reported they 'did not'. In terms of remembering people who played an important role in history, it can be said that the vast majority of the students rarely exhibited this behavior and among the remaining students, those who rarely exhibited this behavior outnumbered those who did not. Finally, in terms of preferring to narrate the events in modern Turkish while teaching historical events, it can be said as a result of the responses given by the preservice teachers that the majority of the students preferred this behavior and among the rest of the students those who rarely preferred this behavior outnumbered those who did not.

Another result obtained in the study was that the historical literacy perceptions of the Social Studies preservice teachers did not differ according to their grade level. In other words, their literacy levels were similar (high) according to their grade levels. Considering whether the social studies preservice teachers' historical literacy perception scores differed according to gender, it was found that there was no difference according to the gender of the preservice teachers. It can be said that the perceptions of the female and male preservice teachers were high regardless of gender, which, in fact, is an expected finding. Unlike this result of the study, in a study in which he aimed to determine the historical literacy perception levels of preservice teachers, Uluçay (2019) concluded that the level of historical literacy differed according to gender. On the other hand, in a study in which they aimed to determine the competencies of Turkish and Social Studies teachers regarding media literacy education and the relationship of these competencies with some variables, Yıldırım and Kardaş (2018) found that the teachers' scores did not differ significantly by gender, which supports the finding of the present study.

When the historical literacy perceptions of the preservice teachers were evaluated according to the education levels of the mother and father, it was found that the educational status of the mother had an effect on the historical literacy perceptions of the preservice teachers, and that the historical literacy scores of the students whose mothers' education levels were high school and above were higher than those whose mothers' education levels were middle school and below. On the other hand, it was determined that the father's education level did not have any effect on the preservice teachers' perceptions of historical literacy, and that their historical literacy levels were similar regardless of whether father's education level was middle school and below or high school and above.

Considering the effect of the pre-service teachers' liking to read books on their perceptions of historical literacy, it was found that the preservice teachers' liking to read books did not affect their historical literacy perceptions. In other words, the students who liked to read history books and those who did not had similar historical literacy perception levels. Similarly, in a study in which they aimed to determine the attitudes of social studies preservice teachers towards oral history studies, Akbaba and Kilcan (2012) concluded that there was no significant difference between the attitudes of the preservice teachers and the variable of the number of historical novels, stories and memoirs they read. Considering the preservice teachers' following historical publications, the scores they received from the scale indicated that the preservice teachers' following historical publications and their historical literacy levels did not differ significantly, and that the historical literacy total, perception, consistency and objectivity scores of the students who followed historical publicationss and those who did not were similar. Unlike the results of the present study, Uluçay (2019) concluded, concerning the pre-service teachers' historical literacy perception levels related to their habits of following historical publications regularly, that in the 
perception sub-dimension, the pre-service teachers who followed historical publications regularly had higher historical literacy perception levels than those who did not. This difference is thought to have arisen from the fact that while the participants of the present study consisted of social studies preservice teachers, the relevant study was conducted with pre-service teachers studying in different undergraduate programs. It was concluded in the present study that the pre-service teachers' frequency of watching historical movies caused a difference on the level of historical literacy, and that the historical literacy and objectivity scores of the students who watched a historical movie once a month or a week were similar and their scores were higher than those who never watched a historical movie. This result can be interpreted to mean that historical movies make a positive contribution to historical literacy. Similar to this result, Kalçı's (2019) study entitled "Investigation of the Perception of Lifelong Learning with Historical Series According to Television Watching " concluded that there was a positive and significant relationship between the frequency of watching historical TV series and lifelong learning. Considering the effect of teacher competence on pre-service teachers' historical literacy perception levels, the students who were affected by their teachers' competence and those who were not had similar historical literacy total, perception, consistency and objectivity scores. In addition, Woelders (2007) stated in this regard that students could use the content, values, and images in movies to construct their own understanding of the past by comparing them with other sources of information.

A general evaluation of the results of the study revealed that the social studies preservice teachers who constituted the sample had high historical literacy perception levels. In addition, their perception levels differed according to the variables of mother's education level and the frequency of watching historical movies, whereas their perceptions did not differ according to the variables of grade level, gender, father's education level, liking to read history books, following historical publications and teacher's competence. It can be said that the social studies preservice teachers' high historical literacy perception levels were a result of the courses with historical content which they took in their undergraduate education. In line with the results of the research, the following suggestions can be made:

- It may be suggested that qualitative and quantitative studies conducted to determine historical literacy perceptions should be increased and they should be compared in terms of different variables.

- Applications can be suggested in different departments (with different samples) at education faculties concerning historical literacy perceptions.

\section{References}

Ahonen, S. (2005). Historical consciousness: A viable paradigm for history education?. Journal of Curriculum Studies, 37(6), 697-707. https://doi.org/10.1080/00220270500158681

Akbaba, B., \& Kilcan, B. (2014). Prospective social studies teachers' attitudes towards oral history studies. Illkögretim Online, 13(3), 746-758.

Akınc1, A. Y. (2020). The relationship between general competency belief and historical literacy perception levels of faculty of sports sciences students. International Journal of Applied Exercise Physiology, 9(10), $36-43$.

Allen, M. G., \& Stevens, R. L. (1998). Middle grades social studies: Teacing and learning for active and responsible citizenship (2nd ed.). New Jersey: Pearson Education.

Ata, B., \& Keçe, M. (2014). The elements affecting students' historical literacy levels: A qualitative research based on teachers' opinions. Turkish History Education Journal, 3(2), 1-23. https://doi.org/10.17497/tuhed.185603

Baildon, M., \& Afandi, S. (2018). History education research and practice: An international perspective. In S. A. Metzger \& L. M. Harris (Eds.), The Wiley International Handbook of History Teaching and Learning (pp. 37-59). SA: Wiley. https://doi.org/10.1002/9781119100812.ch2

Bennett, S. M. (2014). Teachers' beliefs and implementation of historical literacy pedagogy in three advanced placement United States history classrooms. The Georgia Social Studies Journal, 4(2), 53-67.

Ersoy, A. F., \& Öztürk, F. (2015). Patriotism as a citizenship value: Perceptions of social studies teacher candidates. Elementary Education Online, 14(3), 974-992. https://doi.org/10.17051/io.2015.85864

Garcia, J., \& Michaelis, J. U. (2000). Social studies for children: a guide to basic instruction $\left(12^{\text {th }}\right.$ ed.). Boston: Pearson Education Inc.

Kabapınar, Y. (2014). Kuramdan uygulamaya sosyal bilgiler öğretimi. (4. Bask1). Ankara: Pegem Akademi. 
Kalçık, C. (2019). Examination of lifelong learning allegory according to television monitoring status by historical lines. Erzincan Üniversitesi Eğitim Fakültesi Dergisi, 21(1), 113-134. https://doi.org/10.17556/erziefd.413425

Karasar, N. (2005). Bilimsel araştırma yöntemi. Ankara: Nobel Yayın Dağıtım.

Keçe, M. (2009). İlköğretim sekizinci sinıf öğrencilerinin tarih okur-yazarlı̆g durumlarının belirlenmesi (Yayımlanmamış Yüksek Lisans Tezi). Niğde Üniversitesi Sosyal Bilimler Enstitüsü, Niğde.

Keçe, M. (2013). Sosyal bilgiler öğretiminde yararlanılan sınıf içi tarihi roman kullanım tekniklerinin ögrencilerin tarih okuryazarlığı düzeylerine etkisi (Yayımlanmamış Doktora Tezi). Gazi Üniversitesi Eğitim Bilimleri Enstitüsü, Ankara.

Keçe, M. (2015). Comparison of historical thinking skills with historical literacy skills. Karadeniz Sosyal Bilimler Dergisi, 7(3), 108-122.

Khawaja, A. (2018). Designing an assessment tool for historical literacy: The case of Copernicus. Journal Of Humanities And Social Science Education, 3, 1-26.

Köstüklü, N. (2006). Sosyal bilimler ve tarih öğretimi. Konya: Ofset Matbaacılık.

Lee, P. (2005). Historical literacy: Theory and research. History Education Research Journal, 5(1), 29-40. https://doi.org/10.18546/HERJ.05.1.05

Parkes, R. J., \& Donnelly, D. (2014). Changing conceptions of historical thinking in history education: An Australian case study. Revista Tempo e Argumento, 6(11), 113-136. https://doi.org/10.5965/2175180306112014113

Seixas, P. (2017). A model of historical thinking. Educational Philosophy and Theory, 49(6), 593-605. https://doi.org/10.1080/00131857.2015.1101363

Sunal, C. S., \& Haas, M. E. (2005). Social studies for the elementary and middle grades: A constructivist approach $\left(2^{\text {nd }}\right.$ ed.). Boston: Pearson Education.

Taylor, T., \& Young, C. (2003). Making history: A guide for the teaching and learning of history in Australian school. Carlton South: Curriculum Corporation.

Uluçay, C. (2019). Öğretmen adaylarının tarih okuryazarlı̆̆ algı düzeylerinin incelenmesi (Yayımlanmamış Yüksek Lisans Tezi). Erzincan Binali Yıldırım Üniversitesi Sosyal Bilimler Enstitüsü.

Veijola, A., \& Rantala, J. (2018). Assessing Finnish and Californian high school students' historical literacy through a document-based task. Journal of Humanities and Social Science Education, 1, 1-21.

Walker, T. R. (2006). Historical literacy: Reading history through film. The Social Studies, 97(1), 30-34. https://doi.org/10.3200/TSSS.97.1.30-34

Woelders, A. (2007). "It makes you think more when you watch things": Scaffolding for historical inquiry using film in the middle school classroom. The Social Studies, 98(4), 145-152. https://doi.org/10.3200/TSSS.98.4.145-152

Yıldırım, A., \& Şimşek, H. (2016). Sosyal bilimlerde nitel araştırma yöntemleri (10. Baskı). Ankara: Seçkin Yayınevi.

Yıldırım, Ş., \& Kardaş, N. M. (2018). Medıa literacy competencies of Turkish and social studies teachers andcorrelatıon between these competencies and certain varıables. Sosyal Bilimler Enstitüsü Dergisi, 41, 165-182.

\section{Copyrights}

Copyright for this article is retained by the author(s), with first publication rights granted to the journal.

This is an open-access article distributed under the terms and conditions of the Creative Commons Attribution license (http://creativecommons.org/licenses/by/4.0/). 